Western North American Naturalist 68(1), (C) 2008, pp. 25-35

\title{
WINTER AND EARLY SPRING BIRD COMMUNITIES IN GRASSLANDS, SHRUBSTEPPE, AND JUNIPER WOODLANDS IN CENTRAL OREGON
}

\author{
Daniel P. Reinkensmeyer ${ }^{1}$, Richard F. Miller ${ }^{2,5}$, Robert G. Anthony ${ }^{3}$, \\ Vern E. Marr ${ }^{4}$, and Corinne M. Duncan ${ }^{2}$
}

\begin{abstract}
We compared winter (December, January, and February) and early spring (March and April) bird communities among 4 successional stages that included grassland, shrubsteppe, juniper-shrubsteppe, and old-growth juniper woodland in central Oregon. Birds were surveyed monthly from December through April in 1998/1999 and 1999/2000 using the point count method to estimate relative abundance of birds (individuals $\cdot$ transect $^{-1}$ year-1). We used distance sampling to correct for potential bias in estimating abundance and density among successional stages. A total of 4513 birds (32 species) were detected. Relative abundance of total birds (all species combined) was similar in the juniper-shrubsteppe and old-growth woodland (48.7 and 48.9 individuals $\cdot$ transect $^{-1}$, respectively) but 6 times greater than in the grassland and shrubsteppe $\left(8.0\right.$ and 7.7 individuals $\cdot$ transect $^{-1}$, respectively) during the 5-month period. Total density of birds was greater in old-growth juniper woodland and juniper-shrubsteppe than in grassland or shrubsteppe. However, median bird species richness in 1998/1999 was highest in grassland and lowest both in shrubsteppe and juniper-shrubsteppe, and in 1999/2000 it was highest in shrubsteppe and lowest in juniper-shrubsteppe and oldgrowth juniper woodland. American Robins and Townsend's Solitaires were the most abundant species in junipershrubsteppe and old-growth juniper woodland during the winter months. Sage Sparrows and Horned Larks were the most abundant species in shrubsteppe during winter, and Horned Larks were most abundant in grasslands during the early spring transition period prior to nesting. Our results indicate that a different suite of species use these successional stages during the nonbreeding season. If avifauna conservation is a part of long-term management goals, a broad range of successional stages should be maintained on the landscape to provide habitat for a variety of avian species throughout the year.
\end{abstract}

Key words: avian communities, Artemisia, juniper encroachment, old-growth.

Avian communities in the semiarid portion of western North America have been subjected to constant temporal and spatial change in the distribution, composition, and structure of plant communities (Davis 1982, Thompson and Hattori 1983, Miller and Wigand 1994). However, the disruption of historic disturbance regimes due to the increase in human activities since the mid- to late 1800s has changed the structure and function of ecosystems (Pickett and White 1985, Miller and Wigand 1994). Shrubsteppe throughout the Interior West has been altered by the expansion of pinyon and juniper woodlands and the invasion of exotic annual grasses during the 20th century (Burkhardt and Tisdale 1976, Tausch et al. 1981, Miller and Rose 1995, 1999, Soulé and Knapp 2000, Suring et al. 2005). The loss of historic habitats has raised concern for the viability of sagebrush-obligate and grassland-dependent species
(Connelly et al. 2000, Rosenstock and Van Ripper 2001). In the mountain big sagebrush (Artemisia tridentata ssp. vaseyana) alliance, western juniper (Juniperus occidentalis ssp. occidentalis) woodlands have increased 5-10fold in both area and density in the past 140 years (Gedney et al. 1999, Miller et al. 2005, 2008, Johnson and Miller 2006). In addition, the proportions of perennial grasslands maintained by frequent fire-return intervals along the interface between shrubsteppe and forest have also declined (Miller and Rose 1995, Heyerdahl et al. 2006, Miller and Heyerdahl 2008). Because of a combination of perturbations, the sagebrush biome is considered 1 of the most endangered in the United States (Noss et al. 1995). In response, land management agencies have been putting major effort into restoration programs, which are often difficult and have outcomes that are not always

${ }^{1}$ Department of Wildlife and Fisheries, Oregon State University, Corvallis, OR 97331

${ }^{2}$ Eastern Oregon Agricultural Research Center, Department of Range Ecology and Management, Oregon State University, Corvallis, OR 97331 OR 97331

U.S. Geological Survey, Oregon Cooperative Fish and Wildlife Research Unit, Department of Fisheries and Wildlife, Oregon State University, Corvallis,

${ }^{4}$ Oregon Department of Fish and Wildlife, La Grande, OR 97850.

${ }^{5}$ Corresponding author. E-mail: richard.miller@oregonstate.edu 
predictable (U.S. Department of the Interior 1996, Hemstrom et al. 2002). The consequences of landscape restoration strategies and shifts in landscape composition on avifauna conservation should be considered in long-term management plans.

Management practices that alter plant community structure and affect the distribution and composition of successional stages at the landscape level will likely result in changes in avian communities (McArthur and McArthur 1961, McArthur et al. 1962, Karr and Roth 1971, Balda 1975, Roth 1976, Cody 1981). Considerable work has been done to evaluate breeding bird communities in different successional stages, including early and late-seral sagebrush steppe communities and pinyonjuniper woodland (Knick and Rotenberry 1995, Rosenstock and Van Ripper 2001, Noson et al. 2006, Reinkensmeyer et al. 2007). For example, diversity of avian communities was shown to be positively associated with physiognomic cover diversity, and density of breeding birds was greatest in old-growth juniper woodland stands adjacent to sagebrush-steppe communities (Reinkensmeyer et al. 2007). Unfortunately, little is known about bird populations across these successional stages during the winter and early spring, prior to nesting (Maser and Gashwiler 1977). In order to conserve avifauna by manipulating plant community composition across the landscape, we must know what avian species use these landscapes throughout the year.

Composition and structure of plant communities in the mountain big sagebrush cover alliance are largely a function of time intervals between disturbances, particularly fire (Miller and Heyerdahl in press). Disturbance regimes are a primary driver that determines the composition duration of different successional stages across landscapes. Successional stages in the mountain big sagebrush alliance in the Northwest, distinguished by distinct structural states, are perennial grassland (during the first 10+ years), shrubsteppe, and juniper woodland, depending upon the length of time between disturbance events.

The purpose of our study was to evaluate how winter (December, January, and February) and early spring (March and April) bird communities of the mountain big sagebrush alliance that are associated with western juniper utilized 4 different successional stages, all of which are a function of time since disturbance. To do this, we measured avian communities in 4 successional stages associated with mountain big sagebrush that collectively represent a broad range of semiarid upland plant communities in the Intermountain West. We selected old-growth western juniper woodlands, juniper-shrubsteppe (i.e., shrubsteppe in early to intermediate stages of conifer encroachment), shrubsteppe, and native perennial grasslands (resulting from recent burns of mountain big sagebrush habitats) as representatives of these successional stages.

\section{Methods}

Study Areas

Our study area was located in the Mazama and High Desert ecological provinces (Anderson et al. 1998) in Deschutes and Lake counties in central Oregon (Fig. 1). All sites were on lands managed by the Lakeview and Prineville districts of the Bureau of Land Management (BLM). Elevations of our sites ranged from 1110 to $1530 \mathrm{~m}$. Soils were of aeolian origin and made up largely of fine pumice and lakebed sands underlain by basalt. Climate across the study area was characteristic of the northern Great Basin. Mean annual precipitation varied from 25 to $38 \mathrm{~cm}$, falling predominantly as winter and spring snow or rain (Taylor 1993). The 30-year mean average temperature in winter (December-February) was $-1.0^{\circ} \mathrm{C}$ and $4.5^{\circ} \mathrm{C}$ in early spring (March-April; Taylor and Hannan 1999). A large portion of upland vegetation across this region was characterized by mountain big sagebrush steppe, sagebrush steppe in various stages of juniper encroachment, and old-growth western juniper woodland. Persistent and transitory native perennial grasslands also occupied portions of the area. Historically, grassland communities in the area were of 2 types: (1) those which persisted as a result of fire-return intervals $<20$ years, which typically occurred along the pine forest-shrubsteppe interface, and (2) grasslands that were in an early transitory state and developed into shrubsteppe over time where firereturn intervals were $>20$ years (Miller and Rose 1995, Miller and Heyerdahl 2008).

Vegetation on our study area was similar to much of the mountain big sagebrush alliance across the northwestern portion of the sagebrush biome (West 1983, Shiflet 1994). 


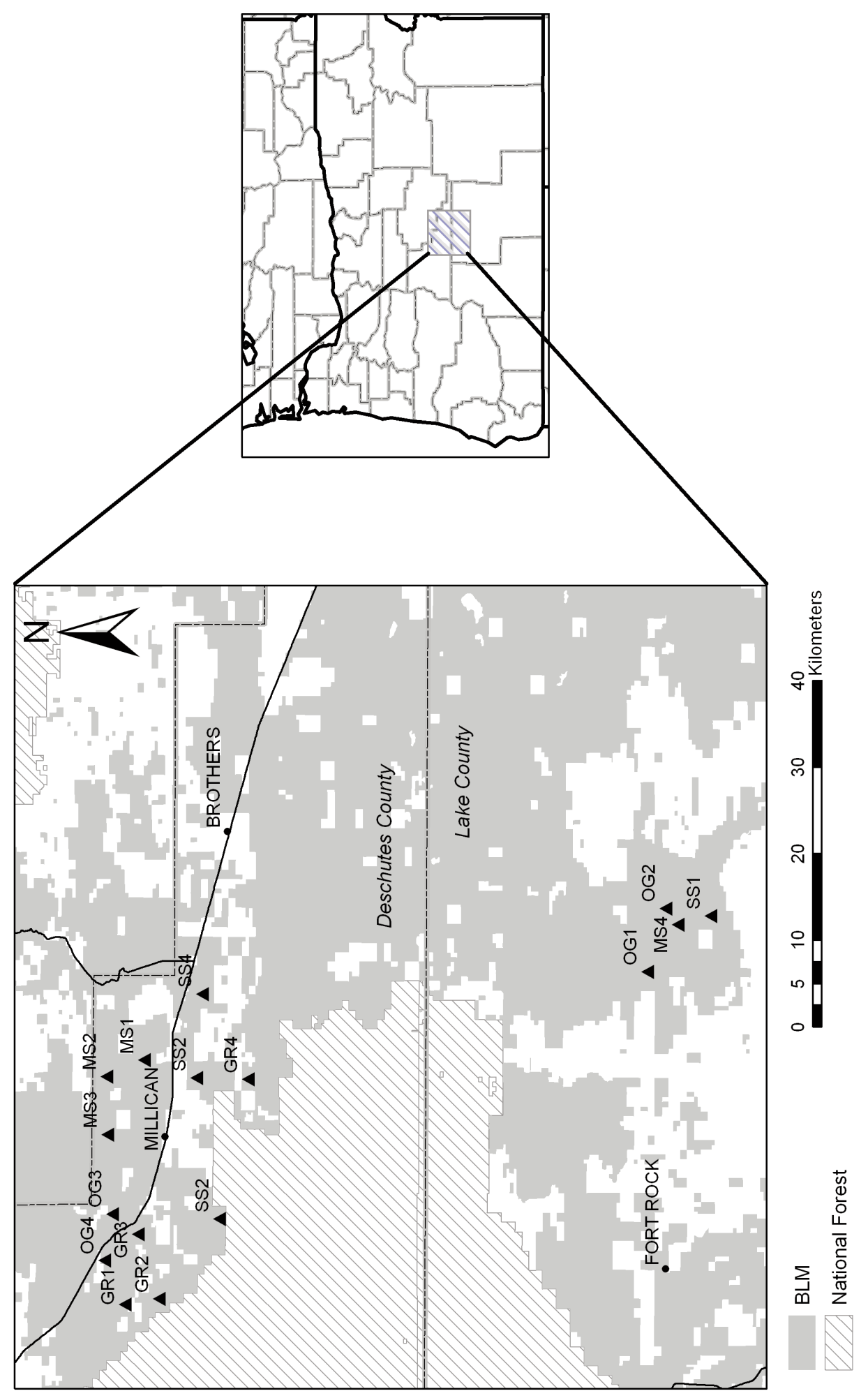

Fig. 1. Map of study area and transect locations $(\mathrm{GR}=$ post-burn grassland, $\mathrm{SS}=$ shrubsteppe, $\mathrm{MS}=$ mid-successional juniper, $\mathrm{OG}=$ old-growth juniper). 
Mountain big sagebrush and green rabbitbrush (Chrysothamnus viscidiflorus) were the most common shrubs across all 4 communities, and Idaho fescue (Festuca idahoensis) and bluebunch wheatgrass (Pseudoroegnaria spicata) were the most common grasses on the grassland, shrubsteppe, and juniper-shrubsteppe (Reinkensmeyer 2000). Adjacent oldgrowth juniper woodland occurred on drier sites as a result of coarse pumice soils that do not hold water very well, resulting in low abundance and continuity of fine fuels. Native perennial grassland sites that we studied had burned within the previous 5 years, each by a different fire, and mean cover of current vegetation was $26.5 \%$ herbaceous and $<5 \%$ shrub, which was mostly the resprouting shrub green rabbitbrush (Reinkensmeyer 2000). Among the shrubsteppe sites, mean vegetation cover was $18.0 \%$ herbaceous vegetation and $18.6 \%$ shrub; mountain big sagebrush was the dominant shrub. The lack of charred wood found in a reconnaissance of all 4 shrubsteppe sites and the results of a measured subsample of age (basal stem growth ring counts) in dominant overstory shrubs indicated that these sites had not burned for $>40$ years. We selected the juniper-shrubsteppe sites based on the juniper woodland development model described by Miller et al. (2005). This successional stage between shrubsteppe and juniper woodland had not burned for $>80$ years, based on the tree age structure. Among these stands, mean plant cover was $13.5 \%$ herbaceous vegetation, $12.6 \%$ shrub, and $6.1 \%$ tree canopy. All trees were postsettlement $(<140$ years old) based on morphological characteristics defined by Miller et al. (2005). Old-growth juniper woodlands were dominated by trees $>300$ years old, cavities and lichens in the tree canopies were common, and stands had an average of 10 standing dead snags $\cdot \mathrm{ha}^{-1}$ (Reinkensmeyer 2000, Waichler et al. 2001). Tree age structure and the presence of only small amounts of charred wood implied that these sites had not been affected by a stand-replacement event for centuries (Waichler et al. 2001). Mean cover was $8.5 \%$ herbaceous vegetation, $5.4 \%$ shrubs, and $23 \%$ tree canopy.

Stand Selection and Sampling Design

We conducted bird surveys on 4 replicates of 4 different successional stages (16 total study sites), including grassland that had burned within the past 5 years, shrubsteppe, junipershrubsteppe, and old-growth juniper woodland (Fig. 1). We used field reconnaissance, aerial photos, and BLM vegetation and soils maps to locate potential study sites within the mountain big sagebrush-Idaho fescue and bluebunch wheatgrass plant associations and adjacent western juniper or old-growth juniper woodland. Each replicate within a successional stage was spatially separate, as no 2 replicates were within the same contiguous block of vegetation. Study sites were $>250$ ha, and we selected them to be as homogeneous as possible within each successional stage based on vegetative structure and topography. We selected study sites that were dominated by native shrubs, forbs, and grasses and that were located where exotic plant species accounted for $<1 \%$ of the ground cover. Reinkensmeyer (2000) and Waichler (1998) provide complete descriptions of vegetation composition and structure of all 16 study sites.

We established a 1.6-km transect on each of the 16 study sites. Each transect consisted of 8 permanently marked sample points located in a systematic-random fashion and spaced at 200-m intervals. A sample point was a single station at which we conducted bird surveys. We randomly located the starting point for each transect near the northern edge of each successional stage, and we placed sampling points systematically along each transect. We oriented transects to maintain the maximum distance from the edge or to exclude different successional stages from the transect's path. Sample points were always located $>100 \mathrm{~m}$ from a different successional stage.

\section{Bird Community Sampling}

Birds were surveyed monthly during the winter (December, January, and February) and early spring (March and April) in 1998/1999 and 1999/2000. Each transect was visited 5 times in each year for a total of 10 visits $\cdot$ transect $^{-1}$ during the winter and early spring. At each sampling point, we used the point count method (Buckland et al. 1993) to estimate relative abundance of birds (individuals $\cdot$ transect $^{-1}$ year $^{-1}$ ). The observer stood at a sampling point for 8 minutes, and after a 1-minute waiting period, recorded all birds that were visually or aurally detected. Bird surveys began 10-20 minutes after sunrise and concluded within 4 hours. We conducted surveys on mornings with wind 
$<15 \mathrm{~km} \cdot \mathrm{h}^{-1}$ and no precipitation. With the aid of rangefinders, we visually estimated the radial distance from each sample point to individual birds. If birds occurred in relatively closely aggregated clusters of $\geq 2$ individuals, the cluster size was recorded and distance to the center of the cluster was estimated. Flagging was tied at known distances from sampling points to aid in distance estimation. Also recorded with each bird detection was whether the bird or cluster of birds was observed within the successional stage being surveyed or within a different successional stage. Because detections were recorded out to an unlimited distance (or radius) at each point, an attempt was made to identify and note detections of birds that may have been detected at neighboring points.

\section{Data Analysis}

ESTIMATION OF AVIAN DENSITY.-We selected only those species observed on $\geq 6$ of the 10 visits and on $\geq 2$ of the 16 transects for density estimation. We selected 6 visits in order to stay consistent with breeding bird surveys done across the same study sites (Reinkensmeyer et al. 2007). We estimated density (birds $\cdot \mathrm{ha}^{-1}$ ) for these common species on each study site using distance sampling (Buckland et al. 1993) and the program DISTANCE version 3.5 (Thomas et al. 1998). When estimating abundance and density, we used distance sampling to correct for potential bias in detection among the 4 successional stages. We pooled all detections of each bird species for both years and each plant community to develop a single detection function for each species in each successional stage. Histograms of the distance data revealed a clumping of observations at certain distances for nearly all species and, in some instances, evidence of minor movement in response to the observer. We ameliorated these problems by grouping the distance data into appropriate but different intervals for each species before selection of the final detection function. We truncated approximately $10 \%$ of the outermost distance data to eliminate outliers and facilitate model fitting (Buckland et al. 1993). We selected the final model based on Akaike's information criterion (AIC) and chisquare goodness-of-fit statistics (Buckland et al. 1993). We computed total density of birds for each successional stage as the sum of densities of individual species.
COMPARISON OF BIRD ASSOCIATIONS AMONG SUCCESSIONAL STAGES.-We compared density among successional stages and years with a repeated-measures 2-way ANOVA using general linear models in SAS (SAS Institute, Inc. 1988). Repeated measures were necessary to accommodate data collected in the 2 different years. We used successional stages as treatments and year in the treatment-by-year interaction. When response variables were not normally distributed or lacked equal variances, we used the square-root, $\log _{\mathrm{e}}$, or $\log _{\mathrm{e}}(\mathrm{Y}+0.01)$ transformations to meet ANOVA assumptions. We used Fisher's LSD test as the multiple comparison procedure to test all pairwise comparisons among successional stages. We set the family-wise confidence level at 95\% (Ramsey and Schafer 1997). Species richness and evenness among successional stages and within years were calculated after adjusting for differences in sample size via the rarefaction method using the program EcoSim 7 (Gotelli and Entsminger 2006). Rarefaction allows for the comparison among samples of unequal size by adjusting all samples to the abundance level of the smallest sample (Heck et al. 1975). Samples among replicates were pooled, and differences between replicates were assumed to be negligible. Species richness was calculated as the total number of species per sample, and evenness was calculated using Hurlbert's PIE:

$$
P I E=\left(\frac{N}{N-1}\right)\left(1-\sum_{i-1}^{s} p_{i}^{2}\right)
$$

where $N$ is the total number of species in a sample, and $p_{i}$ is the proportion of the sample represented by species $i$ (Hurlbert 1971). We set the confidence level at $95 \%$ for both indices.

\section{RESULTS}

A total of 4513 birds (32 species) were detected on 10 visits to 16 transects in 1998/1999 and 1999/2000. We detected 18 species during the winter months (December, January, and February), of which 5 species were detected consistently (Table 1). The most abundant species were the American Robin, Townsend's Solitaire, and Common Raven, which accounted for $87 \%, 7.6 \%$, and $2 \%$, respectively, of the total detections during this 3-month period. During the early spring months (March and 
TABLE 1. Relative abundance and total number of species of all wintering and early spring bird species by month/visit (all successional stages combined) in central Oregon, 1998/1999 and 1999/2000.

\begin{tabular}{|c|c|c|c|c|c|}
\hline & December & January & February & March & April \\
\hline \multicolumn{6}{|l|}{ Species detected consistently ( $\geq 4$ Months) } \\
\hline American Robin (Turdus migratorius) & 469 & 820 & 1198 & 723 & 52 \\
\hline Townsend's Solitaire (Myadestes townsendi) & 61 & 87 & 69 & 67 & 42 \\
\hline Common Raven (Corvus corax) & 20 & 16 & 25 & 33 & 26 \\
\hline Mountain Bluebird (Sialia currucoides) & 1 & 6 & & 34 & 48 \\
\hline Mountain Chickadee (Poecile gambeli) & 12 & 7 & 3 & 10 & 25 \\
\hline Clark's Nutcracker (Nucifraga columbiana) & 4 & 7 & 7 & 6 & 5 \\
\hline Black-billed Magpie (Pica hudsonia) & 1 & 1 & & 5 & 3 \\
\hline Red-tailed Hawk (Buteo jamaicensis) & & 3 & 1 & 2 & 2 \\
\hline \multicolumn{6}{|l|}{ Species detected during 3 months: } \\
\hline Horned Lark (Eremophila alpestris) & & & 3 & 94 & 60 \\
\hline Northern Flicker (Colaptes auratus) & 1 & & & 14 & 92 \\
\hline Dark-Eyed Junco (Junco hyemalis) & & & 1 & 35 & 21 \\
\hline \multicolumn{6}{|c|}{ Species detected only in late winter/early spring (March/April) } \\
\hline Sage Sparrow (Amphispiza belli) & & & & 71 & 77 \\
\hline Western Meadowlark (Sturnella neglecta) & & & & 6 & 35 \\
\hline Pinyon Jay (Gymnorhinus cyanocephalus) & & & & 14 & 13 \\
\hline Sage Thrasher (Oreoscoptes montanus) & & & & & 11 \\
\hline Vesper Sparrow (Pooecetes gramineus) & & & & & 7 \\
\hline Cassin's Finch (Carpodacus cassinii) & & & & & 6 \\
\hline American Kestrel (Falco sparverius) & & & & & 1 \\
\hline Brown-headed Cowbird (Molothrus ater) & & & & & 1 \\
\hline Brewer's Blackbird (Euphagus cyanocephalus) & & & & & 1 \\
\hline Golden-crowned Kinglet (Regulus satrapa) & & & & & 1 \\
\hline Hairy Woodpecker (Picoides villosus) & & & & & 1 \\
\hline Northern Harrier (Circus cyaneus) & & & & & 1 \\
\hline Prairie Falcon (Falco mexicanus) & & & & & 1 \\
\hline \multicolumn{6}{|l|}{ Species detected inconsistently and/or only once: } \\
\hline Golden Eagle (Aquila chrysaetos) & 1 & & 7 & & \\
\hline Northern Shrike (Lanius excubitor) & & 2 & 4 & & \\
\hline Cedar Waxwing (Bombycilla cedrorum) & & 2 & & & \\
\hline Sharp-Shinned Hawk (Accipiter striatus) & & & 1 & & 1 \\
\hline Canada Goose (Branta canadensis) & & & 1 & & \\
\hline Gray-crowned Rosy Finch (Leucosticte tephrocotis) & 1 & & & & \\
\hline Spotted Towhee (Pipilo maculatus) & & & & 1 & \\
\hline Great-horned Owl (Bubo virginianus) & & & 1 & & \\
\hline Total relative abundance & 571 & 951 & 1321 & 1115 & 533 \\
\hline Total species & 10 & 10 & 13 & 15 & 25 \\
\hline
\end{tabular}

April) the number of species detected increased 1.6 times compared to the winter months.

Relative abundance of total birds (all species combined) was similar in the juniper-shrubsteppe and old-growth juniper woodland and 6 times greater in those 2 successional stages than in the grassland and shrubsteppe during the winter and early spring $\left(F_{3,12}=7.30, P=\right.$ 0.0012 ; Table 2 ). Yearly mean relative abundance of total birds was greater in 1999/2000 than in $1998 / 1999\left(F_{3,12}=14.66 ; P=0.0008\right)$. This was a result of large flocks of American Robins (50-350 birds) observed in 1999/2000. Yearly mean relative abundance of all other bird species, with the exception of the American Robin, was similar between years. Both winters were drier than average; however, the winter of 1998/1999 was preceded by a wetter-than-average spring (1998) compared to a drier-than-average spring in 1999. Median bird species richness in 1998-1999 was highest in the grassland and lowest both in the shrubsteppe and juniper-shrubsteppe (Table 3). For 1999-2000 median species richness was highest in the shrubsteppe and lowest in both the juniper-shrubsteppe and old-growth juniper woodland. Densities were estimated for 9 bird species that occurred in $\geq 1$ of the 4 successional stages (Table 2).

Differences in total bird density among successional stages were similar to differences in relative abundance, even after variation in detectability among stages and species was accounted for. Total bird density was significantly 
TABLE 2. Comparison of mean densities (birds $\cdot \mathrm{ha}^{-1} \mathrm{year}^{-1}$ ) and standard errors $\left(\mathrm{s}_{\bar{x}}\right)$ among 4 vegetative successional stages in central Oregon, 1998/1999 and 1999/2000. $0=$ species absent from cover type; $+=$ species present within cover type, but observed infrequently ( $<6$ visits) and/or only 1 transect; $\mathrm{T}=$ trace.

\begin{tabular}{|c|c|c|c|c|c|c|c|c|}
\hline \multirow[b]{2}{*}{ Community measure ${ }^{a}$} & \multicolumn{2}{|c|}{ Grassland } & \multicolumn{2}{|c|}{ Shrubsteppe } & \multicolumn{2}{|c|}{ Juniper/shrubsteppe } & \multicolumn{2}{|c|}{$\begin{array}{l}\text { Old-growth } \\
\text { juniper woodland }\end{array}$} \\
\hline & mean $^{\mathrm{a}}$ & $s_{\bar{x}}$ & mean & $s_{\bar{x}}$ & mean & $s_{\bar{x}}$ & mean & $s_{\bar{x}}$ \\
\hline $\begin{array}{l}\text { Total relative abundance } \\
\left(\text { indiv. } \cdot \text { transect }^{-1} \text { year }^{-1} \text { ) }\right.\end{array}$ & $8.0 \mathrm{a}^{\mathrm{b}}$ & 2.2 & $7.6 \mathrm{a}$ & 1.6 & $48.7 \mathrm{~b}$ & 18.4 & $48.6 \mathrm{~b}$ & 25.2 \\
\hline \multicolumn{9}{|c|}{ Species $^{\mathrm{a}}$} \\
\hline American Robin & $0.138 \mathrm{a}^{\mathrm{b}}$ & 0.062 & $0.058 \mathrm{a}$ & 0.041 & $4.280 \mathrm{~b}$ & 1.333 & $2.899 \mathrm{~b}$ & 1.592 \\
\hline Horned Lark & 0.312 & 0.161 & 0.219 & 0.084 & \multicolumn{2}{|c|}{0} & \multicolumn{2}{|c|}{0} \\
\hline Townsend's Solitaire & \multicolumn{2}{|c|}{+} & \multicolumn{2}{|c|}{+} & 0.166 & 0.032 & 0.205 & 0.054 \\
\hline Sage Sparrow & $0.017 \mathrm{a}$ & 0.017 & $0.465 b$ & 0.146 & $0.120 \mathrm{a}$ & 0.049 & $0 \mathrm{a}$ & \\
\hline Mountain Chickadee & \multirow{2}{*}{\multicolumn{2}{|c|}{+}} & \multicolumn{2}{|c|}{0} & 0.084 & 0.031 & 0.178 & 0.053 \\
\hline Dark-eyed Junco & & + & \multicolumn{2}{|c|}{0} & 0.071 & 0.032 & 0.155 & 0.053 \\
\hline Mountain Bluebird & 0.120 & 0.071 & 0.101 & 0.051 & 0.108 & 0.030 & 0.051 & 0.024 \\
\hline Northern Flicker & $0.001 \mathrm{a}$ & 0.000 & $0.001 \mathrm{a}$ & 0.000 & $0.012 \mathrm{~b}$ & 0.003 & $0.010 \mathrm{~b}$ & 0.003 \\
\hline Western Meadowlark & 0.008 & 0.006 & 0.002 & 0.002 & + & 0 & $\mathrm{~T}$ & 1 \\
\hline Total bird density & $0.596 \mathrm{a}$ & 0.185 & $0.846 a$ & 0.210 & $4.841 \mathrm{~b}$ & 1.402 & $3.496 \mathrm{~b}$ & 1.652 \\
\hline
\end{tabular}

aMean (5 visits $\cdot$ transect $^{-1}$ year $^{-1}$ over a 2 -year; 4 transects per successional stage)

bFisher's LSD test for differences among treatments. Different letters within rows indicate significant differences in pairwise comparisons among treatment means $(P<0.05)$

TABLE 3. Comparison of winter bird community mean species richness and evenness for all detections among 4 vegetative successional stages in central Oregon, 1998/1999 and 1999/2000.

\begin{tabular}{|c|c|c|c|c|c|c|c|c|c|}
\hline \multirow[b]{2}{*}{ Community measure } & \multirow[b]{2}{*}{ Year } & \multicolumn{2}{|c|}{ Grassland } & \multicolumn{2}{|c|}{ Shrubsteppe } & \multicolumn{2}{|c|}{$\begin{array}{l}\text { Juniper/ } \\
\text { shrubsteppe }\end{array}$} & \multicolumn{2}{|c|}{$\begin{array}{l}\text { Old-growth } \\
\text { juniper woodland }\end{array}$} \\
\hline & & mean $^{a}$ & $\mathrm{CI}^{\mathrm{b}}$ & mean & $\mathrm{CI}$ & mean & CI & mean & $\mathrm{CI}$ \\
\hline $\begin{array}{l}\text { Species richness } \\
\left(\text { spp. } \cdot \text { transect }^{-1} \text { year }^{-1}\right)\end{array}$ & $\begin{array}{l}1998-1999 \\
1999-2000\end{array}$ & $\begin{array}{r}12 \\
8\end{array}$ & $\begin{array}{l} \pm 2 \\
\pm 2\end{array}$ & $\begin{array}{l}8 \\
9\end{array}$ & $\begin{array}{l} \pm 2 \\
\operatorname{ars}^{\mathrm{c}}\end{array}$ & $\begin{array}{l}8 \\
5\end{array}$ & $\begin{array}{l} \pm 2.8 \\
\pm 2.0\end{array}$ & $\begin{array}{r}11 \\
5\end{array}$ & $\begin{array}{l} \pm 2 \\
\pm 2\end{array}$ \\
\hline Species evenness $\left(J^{\prime}\right)$ & $\begin{array}{l}1998-1999 \\
1999-2000\end{array}$ & $\begin{array}{l}0.85 \\
0.69\end{array}$ & $\begin{array}{l} \pm 0.04 \\
\pm 0.08\end{array}$ & $\begin{array}{l}0.63 \\
0.84\end{array}$ & $\begin{array}{l}0.06 \\
\text { ars }\end{array}$ & $\begin{array}{l}0.73 \\
0.22\end{array}$ & $\begin{array}{l} \pm 0.06 \\
\pm 0.12\end{array}$ & $\begin{array}{l}0.86 \\
0.22\end{array}$ & $\begin{array}{l} \pm 0.03 \\
\pm 0.12\end{array}$ \\
\hline
\end{tabular}

a Mean (5 visits per transect/year; 4 transects per successional stage).

bConfidence intervals are computed from Monte Carlo simulations at $95 \%$.

${ }^{c}$ Absolute reference sample $=$ smallest sample to which other samples are adjusted for comparison.

greater in $1999 / 2000$ than in $1998 / 1999\left(F_{3,12}\right.$ $=7.30, P \leq 0.0124)$. Total bird density was significantly (4-8 times) greater in junipershrubsteppe and old-growth juniper woodland compared to grassland and shrubsteppe $\left(F_{3,12}=6.98, P=0.0015\right)$.

All bird species for which densities were estimated occurred in $\geq 2$ successional stages. American Robins, Mountain Bluebirds, and Northern Flickers were detected consistently in all 4 successional stages (Table 2). Sage Sparrows were detected in all successional stages except old-growth juniper woodland. However, Sage Sparrow detections were significantly greater in shrubsteppe. Species consistently detected in juniper-shrubsteppe and oldgrowth juniper included Townsend's Solitaires, Mountain Chickadees, and Dark-eyed Juncos. Horned Larks and Western Meadowlarks were detected only in the grassland and shrubsteppe.
American Robins, Sage Sparrows, and Northern Flickers had significantly different densities $(F>10.0, P \leq 0.05)$ among the 4 successional stages (Table 2). American Robins had significantly higher densities in juniper-shrubsteppe and old-growth juniper than in grassland and shrubsteppe $\left(F_{3,12}=9.86, P=0.002\right)$, and they comprised $>80 \%$ of the total bird density in these 2 stages. Sage Sparrows had their highest density in shrubsteppe compared to their densities in the other stages $\left(F_{3,12}=\right.$ 14.93, $P=0.002)$. Horned Larks and Sage Sparrows accounted for $>80 \%$ of the total density of birds in shrubsteppe. Horned Larks, American Robins, and Mountain Bluebirds comprised $>95 \%$ of the total density in grassland. Northern Flickers had significantly higher densities in juniper-shrubsteppe and old-growth juniper than in grassland and shrubsteppe $\left(F_{3,12}=13.58, P=0.0001\right)$. 


\section{Discussion}

Species composition, richness, evenness, and densities during the winter and early spring months differed among the 4 successional stages. Species abundance and composition during the breeding period in May and June also differed from those of the winter and early spring months (Reinkensmeyer et al. 2007). Birds were most abundant in the junipershrubsteppe and old-growth juniper woodland during the winter months. These 2 successional stages provided shelter and food for a number of wintering species by providing juniper berries and ameliorating severe weather conditions (Poddar and Lederer 1982, Leckenby and Adams 1986). Frugivorous birds, particularly American Robins and Townsend's Solitaires, were found at significantly greater densities in the 2 successional stages with juniper. This was presumably due to the availability of juniper berries, which are readily consumed by American Robins (Solomonson and Balda 1977) and are the sole winter food used by Townsend's Solitaires (Lederer 1977, Poddar and Lederer 1982). Winter weather conditions in juniper woodlands are also reported to be less severe $48 \%$ of the time compared to adjacent shrubsteppe communities (Leckenby and Adams 1986). Relative abundance of 48.7 and 48.6 birds $\cdot$ transect $^{-1}$ year $^{-1}$ in the juniper-shrubsteppe and old-growth juniper woodland plots during the winter, respectively, increased to 81.1 and 76 birds . transect $^{-1}$ year $^{-1}$ during the breeding season (May and June) on the same plots (Reinkensmeyer et al. 2007). The most abundant species during the breeding season, the Epidonax flycatchers (primarily Gray and Dusky Flycatchers) and the Chipping Sparrow (Spizella passerine), were absent during winter and early spring.

Total bird density was low and the occurrence of individual species encountered in grassland and shrubsteppe was sporadic during the months of December, January, and February, although these successional stages were important during the breeding and nesting period (Reinkensmeyer et al. 2007). Total bird densities in grassland and shrubsteppe were 8.0 and 7.6 birds $\cdot \mathrm{ha}^{-1}$, respectively, lower than in juniper-shrubsteppe and oldgrowth juniper woodlands. However, species diversity and densities increased in the grass- land and shrubsteppe communities in March and April. Breeding densities on the same plots were 74.6 and 73.2 birds $\cdot$ ha $^{-1}$ in May and June (Reinkensmeyer 2007). The 4 most abundant species in shrubsteppe during the breeding season (Sage Sparrow, Brewer's Sparrow [Spizella breweri], Vesper Sparrow, and Horned Lark) were absent during the winter months. The majority of grassland and shrubsteppe bird species during the breeding season were insectivorous (Rotenberry and Wiens 1978) and migrated south during the winter. Many species detected primarily in grassland and/or shrubsteppe, such as Horned Larks, Sage Sparrows, Vesper Sparrows, Western Meadowlarks, and Sage Thrashers, were detected only in early spring, just prior to the breeding season. These species were likely a combination of transients and early arrival nesters. The near absence of Horned Larks during the winter months across our study area was not expected. This species forages on both seeds and insects (Sibley 2001) and occurs in eastern Oregon during the winter (Contreras 1997). However, during the nonbreeding season, Horned Larks form large nomadic flocks, and more northerly species are known to be migratory (Sibley 2001). Although abundance and density were lower in grassland and shrubsteppe, median bird species richness in those areas tended to be greater than it was in juniper-shrubsteppe and old-growth juniper. This was a result of the high proportion of American Robins and Townsend's Solitaires in the juniper communities and the influx of species in shrubsteppe and grassland during the early spring.

American Robins were by far the most abundant bird species encountered on the study area and were present during the months of severe winter weather (December, January, and February). They were often observed in large flocks of up to 350 individuals and made up $88 \%$ and $83 \%$ of total bird density in junipershrubsteppe and old-growth juniper, respectively. American Robins were present in grassland and shrubsteppe, but they occurred at much lower densities in these successional stages than in the other 2 stages. Numbers of American Robins peaked during January, February, and March, and then declined rapidly in April as the majority of the birds returned to breeding areas elsewhere. American Robin winter and early spring densities of 4.3 and 
2.9 birds $\cdot \mathrm{ha}^{-1}$ in the juniper-shrubsteppe and old-growth juniper woodland plots declined to 0.12 and 0.13 birds $\cdot$ ha $^{-1}$ during the breeding season on the same plots (Reinkensmeyer et al. 2007).

Townsend's Solitaires were the 2nd-most abundant bird $(7.3 \%)$ during the sampling period and were consistently found from December through April. Densities of Townsend's Solitaires had rapidly declined by early May, and they were absent during the breeding season (Reinkensmeyer et al. 2007) because they breed primarily in coniferous forests. Unlike American Robins, Townsend's Solitaires were encountered as individuals or in groups of 2 , and never in large flocks. Clark's Nutcrackers were encountered consistently throughout the winter and early spring in the old-growth juniper woodland, but sporadically in the other successional stages.

The successional stages we investigated are primarily a function of disturbance, topography, and soils. Fire is 1 of the primary disturbance factors in this vegetation (Miller and Tausch 2001, Knick et al. 2005), and the number of years between fire events is a key driver that determines the proportion and persistence of these successional stages in both time and space (Johnson and Miller 2006, Miller and Heyerdahl in press). Historically, fire sizes varied at multiple scales (i.e., 10s, 100s, and 1000s of hectares) in the sagebrush biome, with fire-return intervals ranging from decades to centuries likely due to soil and topographicdriven variation in the amount and continuity of fine fuel (Miller and Heyerdahl in press). The spatial and temporal variation in fire-return intervals resulted in both the persistence and continual flux of successional stages, which created a mosaic of plant communities across the landscape. These mosaics of varying successional stages are important in providing habitats for different avian species throughout the year. However, during the 20th century, the heterogeneity of fire-return intervals has declined across much of the mountain big sagebrush alliance (usually the intervals have become longer) due to several factors, including the reduction of fine fuels by livestock grazing and fire suppression (Miller and Tausch 2001). The consequence has been an increase in pinyon and juniper woodland and transitional juniper-shrubsteppe in this alliance and a decline in grassland and shrubsteppe communities, both of which result in a decline in landscape heterogeneity. This loss has been exacerbated by the decline of more arid sagebrush-steppe cover types, such as Wyoming big sagebrush (Artemisia tridentata ssp. wyomingensis), caused by the invasion and persistence of exotic grasses (Suring et al. 2005) that result in shorter fire-return intervals. Our results indicate that a different suite of species uses these successional stages at different times of the year. Consequently, a mosaic of different successional stages is important in maintaining a diversity of bird species that use these landscapes during the winter, the early spring (our results), and the breeding season (Reinkensmeyer et al. 2007). If 1 of the goals of management is to maintain habitat for a variety of bird species throughout the year, managers should maintain a broad range of successional stages.

\section{ACKNOWLEDGMENTS}

The Partners in Flight-U.S., the Oregon Department of Fish and Wildlife, and the Eastern Oregon Agricultural Research Center (EOARC) funded this project. The Oregon State University Agricultural Experiment Station and the USDA Agricultural Research Service jointly operate EOARC.

\section{Literature Cited}

Anderson, E.W., M.M. Borman, and W.C. Krueger. 1998. Ecological provinces of Oregon: a treatise on the basic ecological geography of the state. Oregon Agricultural Experiment Station, SR 990, Corvallis, OR.

BALDA, R.P. 1975. Vegetation structure and breeding bird diversity. Pages 59-80 in D.R. Smith, technical coordinator, Proceedings-management of forest and range habitats for nongame birds. General Technical Report GTR-WO-1, USDA Forest Service.

Buckland, S.T., D.R. Anderson, K.P. Burnham, and J.L. LAAKE. 1993. Distance sampling: estimating abundance of biological populations. Chapman and Hall, London.

Burkhardt, J.W., and E.W. Tisdale. 1976. Causes of juniper invasion in southwestern Idaho. Ecology 76 : 472-484.

Cody, M.L. 1981. Habitat selection in birds: the roles of vegetation structure, competitors, and productivity. BioScience 31:107-113.

Connelly, J.W., M.A. Schroeder, A.R. Sands, and C.E. Braun. 2000. Guidelines to manage sage grouse populations and their habitats. Wildlife Society Bulletin 28:967-985.

Contreras, A. 1997. Northwest birds in winter. Oregon State University Press, Corvallis. 
DAVIS, J.O. 1982. Bits and pieces: the last 35,000 years in the Lahontan area. Society of American Archeology Paper 2:53-75.

Gedney, D.R., D.L. Azuma, C.L. Bolsinger, and N. MCKAY. 1999. Western juniper in eastern Oregon. General Technical Report NW-GTR-464, USDA Forest Service, Pacific Northwest Experiment Station, Portland, OR.

Gotelli, N.J., And G.L. Entsminger. 2006. EcoSim: null models software for ecology. Version 7. Acquired Intelligence Inc. \& Kesey-Bear, Jericho, VT. Available from: http://garyentsminger.com/ecosim.htm

Heck, K.L., Jr., G. van Belle, and D. Simberloff. 1975. Explicit calculation of the rarefaction diversity measurement and the determination of sufficient sample size. Ecology 56:1459-1461

Hemstrom, M.A., M.J. Wisdom, W.J. Hann, M.M. RowLAND, B.C. Wales, and R.A. Gravenmier. 2002. Sagebrush-steppe vegetation dynamics and restoration potential in the interior Columbia Basin, U.S.A. Conservation Biology 16:1243-1255.

Heyerdahl, E.K., R.F. Miller, and R.A. Parsons. 2006. History of fire in Douglas-fir establishment in a savanna and sagebrush-grassland mosaic, southwestern Montana. Forest Ecology and Management 230:107-118.

HurlberT, S.H. 1971. The nonconcept of species diversity: a critique and alternative parameters. Ecology 52: $577-586$.

Johnson, D.D., AND R.F. Miller. 2006. Structure and development of expanding western juniper woodlands as influenced by two topographic variables. Forest Ecology and Management 229:7-15.

KARR, J.R., AND R.R. RoTH. 1971. Vegetation structure and avian diversity in several new world areas. American Naturalist 105:423-435.

Knick, S.T., A.L. Holmes, and R.F. Miller. 2005. The role of fire in structuring sagebrush habitats and bird communities. Studies in Avian Biology 30:63-75.

KNICK, S.T., AND J.T. RotenberRy. 1995. Landscape characteristics of fragmented shrubsteppe habitats and breeding passerine birds. Conservation Biology 9: 1059-1071.

LeCKenby, D.A., AND A.W. AdAms. 1986. A weather severity index on mule deer winter range. Journal of Range Management 39:244-248.

LEDERER, R.J. 1977. Winter territoriality and foraging behavior of the Townsend's Solitaire. American Midland Naturalist 97:101-109.

Maser, C., AND J.S. Gashwiler. 1977. Interrelationships of wildlife and western juniper. Pages 37-82 in Proceedings-western juniper ecology and management workshop. General Technical Bulletin PNWGTR-4, USDA Forest Service, Pacific Northwest Experiment Station, Portland, OR.

McArthur, R.H., And J.W. McArthur. 1961. On bird species diversity. Ecology 42:594-598.

McArthur, R.H., J.W. McArthur, and J. Preer. 1962. On bird species diversity. II. Prediction of bird census from habitat measurements. American Naturalist 96:167-174.

Miller R.F., J.D. Bates, T.J. Svejcar, F.B. Pierson, L.E. Eddleman. 2005. Biology, ecology, and management of western juniper (Juniperus occidentalis). Oregon State University Agricultural Experiment Station Technical Bulletin Number 152, Corvallis, OR.
Miller, R.F., and E.K. Heyerdahl. 2008 [in press]. Finescale variation in fire regimes in the northern sagebrush biome: an example from California, USA. International Journal of Wildland Fire 17.

Miller, R.F., AND J.A. Rose. 1995. Historic expansion of Juniperus occidentalis (western juniper) in southeastern Oregon. Great Basin Naturalist 55:37-45.

. 1999. Fire history and western juniper encroachment in sagebrush steppe. Journal of Range Management 52:550-559.

Miller, R.F., and R.J. Tausch. 2001. The role of fire in juniper and pinyon woodlands: a descriptive analysis. Pages 15-30 in K.E.M.Galley and T. Wilson, editors, Proceedings of the Invasive Species Workshop: the role of fire in the control and spread of invasive species. Fire Conference 2000: The First National Congress on Fire Ecology, Prevention, and Management. Miscellaneous Publication 11, Tall Timbers Research Station, Tallahassee, FL.

Miller, R.F., R.J. Tausch, E.D. McArthur, D.D. JohnSON, AND S.C. SANDERSON. 2008. Age structure and expansion of piñon-juniper woodlands: a regional perspective in the Intermountain Region. Research Paper Report RMRS-RP-69. USDA Forest Service, Rocky Mountain Experiment Station, Ogden, UT.

Miller, R.F., and P.E. Wigand. 1994. Holocene changes in semiarid pinyon-juniper woodlands: response to climate, fire and human activities in the US Great Basin. BioScience 44:465-474.

Noson, A.C., R.A. Schmitz, And R.F. Miller. 2006. Influence of fire and juniper encroachment on birds in high-elevation sagebrush steppe. Western North American Naturalist 66:343-353.

Noss, R.F., E.T. LaRoe, III, AND J.M. ScotT. 1995. Endangered ecosystems of the United States: a preliminary assessment of loss and degradation. National Biological Service Biological Report 28, Washington, DC.

PicketT, S.T.A., AND P.S. WHitE. 1985. The ecology of natural disturbance and patch dynamics. Academic Press, New York.

PodDAR, S., AND R.J. LEDERER. 1982. Juniper berries as an exclusive winter forage for Townsend's Solitaires. American Midland Naturalist 108:34-40.

Ramsey, F.L., AND D.W. SChafER. 1997. The statistical sleuth: a course in the methods of data analysis. Duxbury Press, Belmont, CA.

Reinkensmeyer, D.P. 2000. Habitat associations of bird communities in shrub-steppe and western juniper woodlands. Master's thesis, Oregon State University, Corvallis, OR.

Reinkensmeyer, D.P., R.F. Miller, and R.G. Anthony. 2007. Changes in avian communities along a mountain big sagebrush successional gradient. Journal of Wildlife Management 71:1057-1066.

Rosenstock, S.S., And C. Van Riper, III. 2001. Breeding bird responses to juniper woodland expansion. Journal of Range Mangement 54:226-232.

Rotenberry, J.T., AND J.A. Wiens. 1978. Nongame bird communities in northwestern rangelands. Pages 3246 in R.M. DeGraff, editor, Proceedings-workshop on nongame bird habitat management in coniferous forests of the western United States. General Technical Report GTR-PNW-64, USDA Forest Service, Pacific Northwest Experiment Station, Portland, OR.

Roth, R.R. 1976. Spatial heterogeneity and bird species diversity. Ecology 57:773-782. 
SAS Institute, Inc. 1988. SAS procedures guide. Release 6.03. SAS Institute, Inc., Carey, NC. 441 pp.

ShifLET, T.N., EDITOR. 1994. Rangeland cover types of the United States. Society for Range Management, Denver, CO.

Sibley, D.A. 2001. The Sibley guide to bird life and behavior. Alfred A. Knopf, New York.

SOLOMONSON, M.G., AND R.P. BALDA. 1977. Winter territoriality of Townsend's Solitaire (Myadestes townsendi) in a pinyon-juniper-ponderosa pine ecotone. Condor 79:148-161.

SOUlé, P.T., AND P.A. KNaPP. 2000. Juniperus occidentalis (western juniper) establishment history on two minimally disturbed research natural areas in central Oregon. Western North American Naturalist 60:2633.

Suring, L.H., M.J. Wisdom, R.J. Tausch, R.F. Miller, M.M. Rowland, L. Schueck, and C.W. Meinke. 2005. Modeling threats to sagebrush and other shrubland communities. Pages 94-113 in M.J. Wisdom, M.M. Rowland, and L.H. Suring, editors, Habitat threats in the sagebrush ecosystem: methods of regional assessment and applications in the Great Basin. Alliance Communications Group, Lawrence, KS.

Tausch, R.J., N.E. West, and A.A. Nabi. 1981. Tree age and dominance patterns in Great Basin pinyonjuniper woodlands. Journal of Range Management 34:259-264.

TAYLOR, G.H. 1993. Normal annual precipitation; state of Oregon. Oregon Climate Service, Oregon State University, Corvallis.

TaYlor, G.H., and C. Hannan. 1999. The climate of Oregon: from rain forest to desert. Oregon State University Press, Corvallis.
Thomas, L., J.L. Laake, J.F. Derry, S.T. Buckland, D.L. Borchers, D.R. Anderson, K.P. Burnham, ET AL. 1998. Distance 3.5. Research Unit for Wildlife Population Assessment, University of St. Andrews, St. Andrews, U.K.

Thompson, R.S., and E.M. Hattori. 1983. Packrat (Neotoma) middens from Gatecliff Shelter and Holocene migrations of woodland plants. Pages 157-167 in D.H. Thomas, editor. The archaeology of Monitor Valley. 2. Gatecliff Shelter. Anthropology Paper American Museum of Natural History 59.

U.S. Department of the Interior. 1996. Effects of military training and fire on habitats, prey and raptors in the Snake River Birds of Prey National Conservation Area. United States Geological Survey, BLM/ IDARNG Final Report, Boise, ID.

WAICHLER, W.S. 1998. Community structure of old-growth Juniperus occidentalis woodlands. Master's thesis, Oregon State University, Corvallis.

Waichler, W.S., R.F. MilleE, AND P.S. Doescher. 2001. Community characteristics of old-growth western juniper woodlands in the pumice zone of central Oregon. Journal of Range Management 54:518-527.

WEST, N.E. 1983. Western intermountain sagebrush steppe. Pages 351-373 in N.E. West, editor, Temperate deserts and semi-deserts. Ecosystems of the world 5. Elsevier Scientific Publishing Company, New York.

Received 21 February 2007 Accepted 28 August 2007 